\title{
Et svar på anmeldelsen i RvT 49 af Gyldendals Leksikon om Nordisk Mytologi
}

Det er fuldstændig uhørt, at de samme to anmeldere nu hele tre gange har været ude med riven i en anmeldelse af min bog Gyldendals Leksikon om Nordisk Mytologi. Jeg kan ikke mindes at have set den samme anmelder anmelde en bog hele tre forskellige steder og må opfatte det som en ganske voldsom overskridelse af uskrevne normer i dansk åndsliv.

I Lexico-Nordica 13, 2006, gav de en omfattende kritik. Kritikken var så voldsom, at redaktøren bad dem om at moderere sig og opfordrede mig til at give et lille modpip i samme nummer. Men de fortsatte blot, med en forkortet version i Folk og Kultur. Årbog for Dansk Etnologi og Folkemindeskab, 2007, og en 3., ligeledes forkortet version, i RvT 49, s. 99-101. Også i RvT fik de at vide, at de skulle moderere sig, men fik altså desværre - optaget anmeldelsen. Måske er der en vis mildning i tonen i de to kortere anmeldelser, men det er fortsat beskæmmende, at de blot fortsætter med deres enøjethed; deres fire øjne har slet ikke set bogens kvaliteter, som har været så indlysende for alle andre anmeldere, og de har heller ikke taget mine bemærkninger til sig, eller også vil de ikke.

Måske burde jeg blot sige til mig selv, at sådan er de altså. Eller at der ikke går noget skår af mig, fordi bogen er blevet skævt anmeldt i tre tidsskrifter, når den ellers måske 15 gange er blevet rosende anmeldt i aviser, andre tidsskrifter, og andre medier, bl.a. Danmarks Radio, og i øvrigt stort "sat op" i interview i bl.a. Berlingske Tidende, Frederiksborg Amts Avis, Danmarks Radio og Sky Radio. Salgstallet er også meget højt, i alt vel ca. 17.000 eksemplarer i løbet af små to år; den er kommet i tre bogklubber hos Gyldendal: Samlerens, Gyldendals og Lærernes. Samlet har altså omkring 50.000 læst den og bruger den.

Bogen er led i en serie i forlængelse af Den Store Danske Encyklopædi. Bl.a. derfor er forordet ikke omfatttende. Læserkredsen giver derfor sig selv: Det er encyklopædibrugeren, men også den egentlige fagmand, fordi der naturligvis står mere i mit leksikon, 
og også en gruppe yngre læsere med interesse for mytologi, bl.a. fordi jeg lægger vægt på det fortællende stof.

Som eksempel på bogens både brede og dybe mulighed, kan jeg nævne, at en anmelder - en absolut fagmand - kaldte bogen "fremragende formidling", skrev at han selv var blevet belært, og at hans søn i 7. klasse også syntes, det var spændende læsning. Det er sådan en dobbelthed, der glæder. Jeg har også øvet mig på denne formidlingsform i over 30 år, ved at skrive i Gyldendals almindelige leksika, i Gyldendals Religionsleksikon og i Encyklopædien; i alle sammenhænge har jeg bl.a. taget mig af det nordiske stof (i Encyklopædien sammen med Jens Peter Schjødt og Claus Jensen). Jeg er ikke videnskabsmand, men fagmand (i dansk litteratur, i religion og i folkemindevidenskab), formidler, forfatter.

Overalt har det lydt, at bogen er fremragende skrevet, formidlingen i top, og at bogens scoop er det virkningshistoriske (fx litterær og billedkunstnerisk påvirkning og brug), som jo netop ikke kan findes andre steder, men bygger på mange års læsning og sammenkædning. Dette indlysende perspektiv i bogen nævner de to anmeldere slet ikke, og det må i sandhed kaldes - graverende. Billedstoffet, som anmelderne også har været ude efter, er netop også perspektiverende. Måske forestiller anmelderne sig en rent videnskabelig, billedløs fremstilling, som den i Simeks tørt-kompakt-tyske Lexikon der germanischen Mythologie. Den er god og supergrundig, men min er altså af en anden fremstillingsform

I stedet for opholder de sig ved, at der mangler opslagsord. Nej, det gør der ikke i forhold til mine udvalgskriterier. Det har ikke været min hensigt at tage revl og krat med; det ville nok have medført et antal på omkring 1500 rent mytologiske opslagsord, mens jeg vel har 500 og 300 perspektivord. De ord, de nævner som "mangler" er virkelig perifere, ja, ganske overflødige, efter min mening. Det eneste ord, der kunne bruges, er J. Grimm; men i betragtning af, at jeg kun har en artikel om én udenlandsk forsker, Dumézil, er det nok i overkanten at kritisere "manglen" (han kunne nævnes i afsnittet om Tyskland i Efterskriften); lodkastning nævnes adskillige steder i værket, men har ikke et specifikt opslag.

Anmelderne bruger en leksikografisk jargon, som virker skæv. En "lemmabestand" er et gyseligt begreb i stedet for det gode "opslagsord", og "ordbog" i stedet for "leksikon" eller "opslagsværk" giver læseren forkerte associationer. Min "ordbog" består selvfølgelig af et stort antal ganske korte opslag, men også af over 100 lange, ofte næsten essayistiske artikler. Jeg varierer mellem fortælling, resumé, redegørelse, analyse, fortolkning og perspektivering og skriver pointeret, sammenlignende og fænomenologisk. Den nyeste forskning inden for mine områder er søgt formidlet i forståelig form. Anmelderne er tydeligvis ikke på hjemmebane, når det drejer sig om litterær analyse og fortolkning og om religionsvidenskab.

Med hensyn til mit valg af staveformer: Det er umuligt at være helt konsekvent, fordi man dels gerne vil rette sig efter de norrøne former, dels bruge de former der er blevet gængse på dansk. I nogle tilfælde, fx i forbindelse med eddadigtenes titler, har jeg valgt de norrøne former som hovedopslag, fordi de danske forekom mig upræcise; 
i andre tilfælde, fx ved så hyppige ord som Odin, Loke, Freja, har jeg valgt de danske og angivet den norrøne form derefter. Men under alle omstændigheder får man problemer; hvordan skal man fx gengive ord med Hl-? Krydshenvisninger klarer dog vel det meste.

Enhver bog med en sådan kompleksitet vil rumme fejl og inkonsekvenser; selv det vel mest gennemresearchede og -redigerede bogværk, Encyklopædien, var for hvert bind forsynet med et rettelsesblad. Anmelderne har fundet nogle stykker i min bog, og de skal naturligvis rettes i kommende oplag/udgaver; disse fund kan jeg være dem taknemmelig for, men ikke tonen af bedreviden og blær. Det er rigtigt, at der burde stå "fællesnordisk" i stedet for "norrønt" i forbindelse med svensk; men det er en tanketorsk og burde ikke medføre den lange oplysning om, hvordan svensk udvikler sig. Pladsen kunne bruges til at karakterisere min bogs iøjnefaldende kvaliteter.

Afslutningsvis et par ord om det at anmelde. En anmelder skal være kritisk, dvs. vægte kvaliteter og mangler. Der skal ikke være tale om én stor omgang ros, men heller ikke det modsatte. En anmelder skal ikke være skarpretter, foretage skoleridt eller være enøjet, men folde et værk ud i hele dets bredde. Her forsynder de to anmeldere sig; dels mangler de urbanitet, og dels fremgår det slet ikke, hvad bogen formidler af ikke mindst læseglæde og virkningshistorisk perspektivering.

Finn Stefánsson Peblingevej 58 4000 Roskilde 